\title{
EMERALDS AND GREEN BERYLS OF UPPER EGYPT
}

\author{
By Robert H. Jennings, Robert C. Kammerling, André Kovaltchouk, Gustave P. Calderon, \\ Mohamed K. El Bar, and John I. Koivula
}

Egypt is the most ancient of sources for emerald. More than 2,000 years ago, emerald deposits in upper Egypt were supplying gems throughout the Graeco-Roman Empire. A recent visit to this emerald province revealed that the emeralds occur within a northwestsoutheast trending belt of schistose rocks in the Red Sea Hills, near the port town of Marsa Alam. At the time of the visit, there was no official commercial mining of emerald in the region, although there was evidence of sporadic activity by Bedouin tribespeople. Gemological examination of 14 cut emeralds and green beryls revealed properties consistent with those of material from similar geologic environments.

\footnotetext{
ABOUT THE AUTHORS

Mr. Jennings is former senior geologist, Mr. Kovaltchouk is former chief geophysicist, and Mr. El Baz is former staff geologist, ARCO Suez Inc., Cairo, Egypt; Mr. Kammerling is director of Identification and Research, Mr. Calderon is a staff gemologist, and Mr. Koivula is chief research gemologist, GIA Gem Trade Laboratory, Santa Monica, Califomia.

Acknowledgments: The authors thank C. A. Barker and M. J. Welland for their support and permission to use ARCO vehicles and equipment. Ali Khorrassany accompanied the research group in the field and provided study material. The hospitality of the Egyptian Geological Survey and Mining Authority in Marsa Alam is greatly appreciated. Derek Content kindly provided the text for box $A$. Sam Muhimeister and Mike Moon of GIA Research gathered the EDXRF and infrared spectroscopy data, respectively. Carol Silver did the map artwork.

Gems \& Gemology, Vol. 29, No. 2, pp. 100-115.

(C) 1993 Gemological Institute of America
}

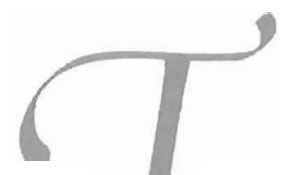

he legendary "Cleopatra's Mines" were the single most important source of emeralds for most of recorded history, with the earliest known production dating to the fourth century B.C. In fact, until the Spaniards' 16th-century discovery of emerald deposits in what is now Colombia, Egypt was the only significant source of this beryl variety as a gem material (Sinkankas, 1981). Yet in spite of their long history, relatively few early Egyptian emeralds are known (figure 1), with only a small number having been found in ancient tombs (Gregorietti, 1969). Sinkankas (1981) concludes from this relative scarcity of historic stones that large quantities were not produced from these mines, and the stones recovered were small and of "mediocre" quality. He further speculates that such material was probably used primarily in amulets or was crushed for medicinal use. The mines themselves have been largely inactive for more than 700 years, with 19 th- and 20thcentury attempts to reestablish commercial operations singularly unsuccessful.

Consequently, relatively little has been published on Egypt's emerald deposits-especially maps of the various occurrences and reports of current recovery-or on the gemology of the gems themselves. Although Grubessi et al. (1990) provided some gemological and crystallographic data for beryl crystals from Gebel Zabara, there has been no detailed gemological characterization of the gem-quality fashioned material that is available today.

It is commonly believed that the commercial potential of the Egyptian emerald deposits is low because of the generally poor quality of the material and the remoteness of the area, its harsh climate, and the consequent high cost of mining. Nevertheless, limited quantities of emeralds are recovered from the region today. No production figures are available, but small amounts of faceted and cabochon material are occasionally available for purchase in the town of Luxor, in the Nile Valley of upper Egypt. Rough and fashioned material from the region is also sometimes sold in Cairo's Khan il Khalili Bazaar. 


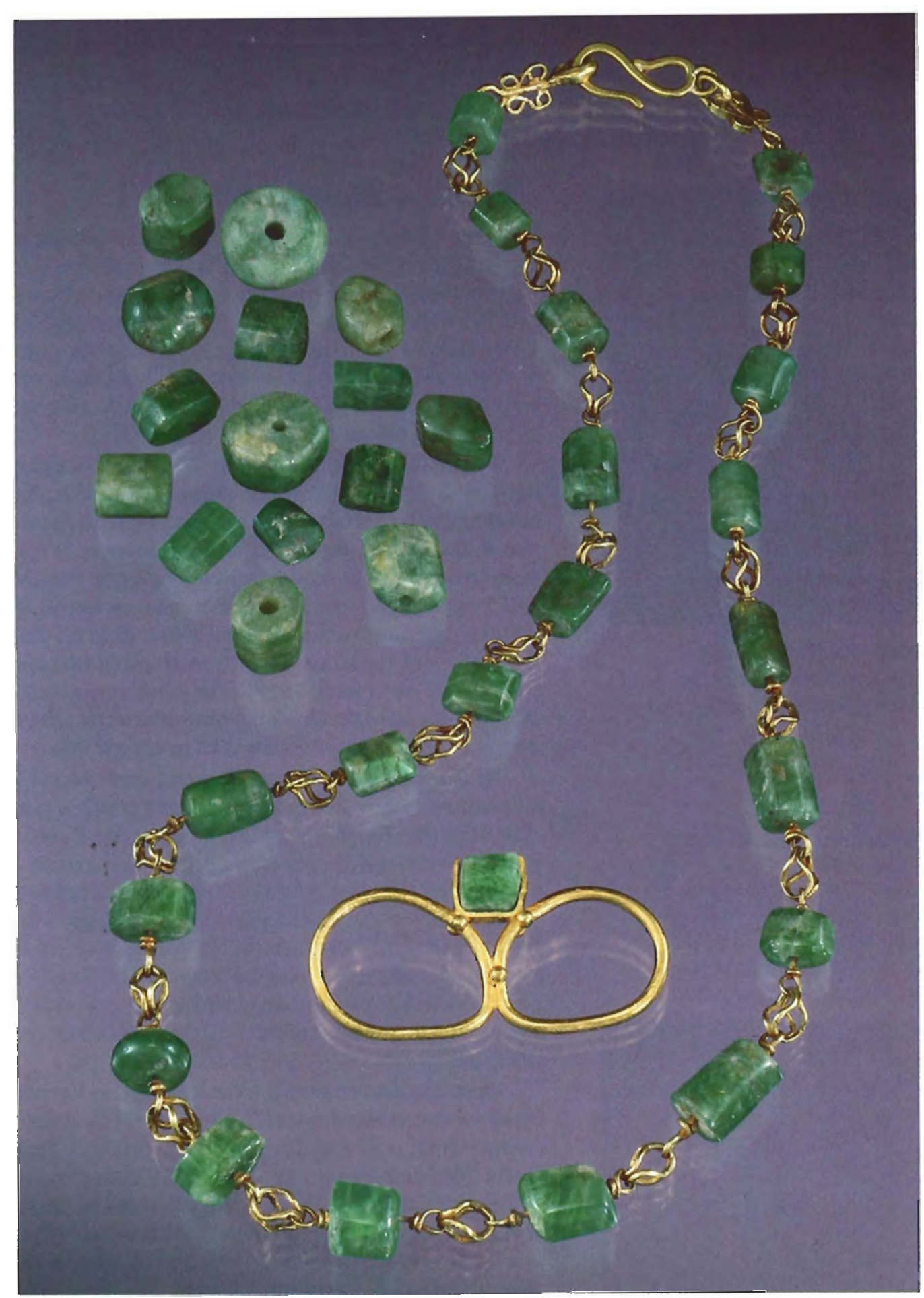

Figure 1. This EgyptoRoman necklace and Graeco-Roman ring, both containing emeralds believed to be from upper Egypt, help illustrate the historic significance of the gems from this source. The loose stones are typical of the emeralds and green beryls that have been produced from this region over the centuries. The emerald in the ring, which is courtesy of Th. Horovitz a) Cie., is $8.88 \times 5.90 \mathrm{~mm}$. The necklace and loose stones are courtesy of Derek Content, Inc., Houlton, Maine, Photo (c) Harold e) Erica Van Pelt.

Some of this material is quite attractive, especially when enhanced by fracture filling (figure 2).

Four of the authors (RH), RCK, AK, MEB) traveled to the Zabara, Sikheit, Nugrus, and Umm Kabu emerald localities of upper Egypt from November 30 to December 7, 1991. The objectives of this excursion were to: (1) determine the current extent of emerald recovery in this region; (2) update existing locality maps and draft new ones for areas previously not surveyed (such as Umm Kabu); and (3) if possible, obtain material for gemological study.
This article briefly reviews access to, and the geology of, some of the localities where emeralds and green beryls have been mined in upper Egypt, as well as what is known of past and present recovery activities. Revised locality maps of the mining areas that were visited are presented, as is a previously unpublished access map to the mines of the Umm Kabu region, where most of the current recovery activity appears to be focused. The gemological characteristics of fashioned emeralds recently obtained from the region are described. 


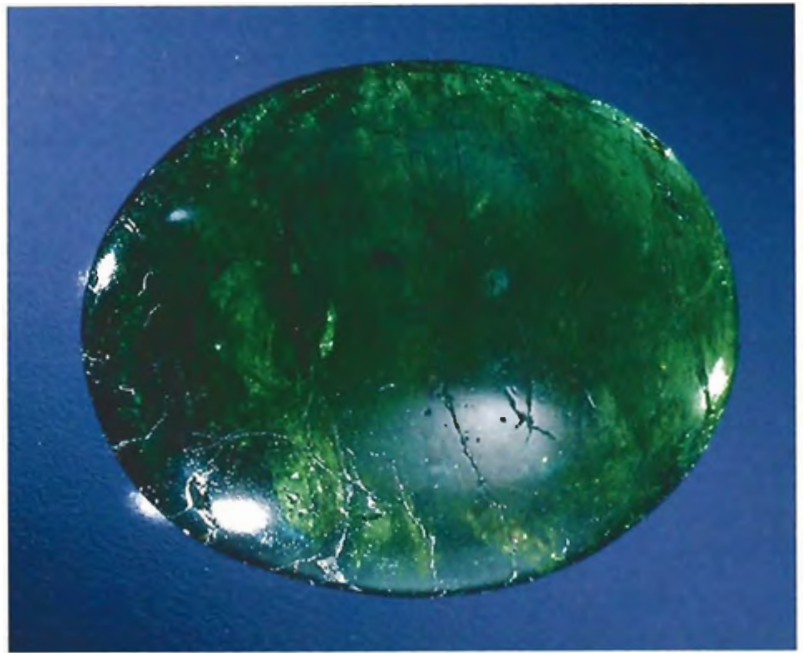

Figure 2. This 14.56-ct emerald cabochon was obtained recently in Egypt and subsequently fracture filled. Photo (C) GIA and Tino Hammid.

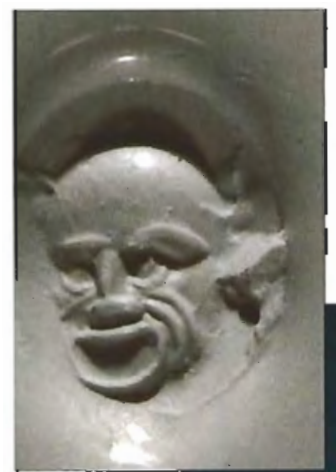

Figure 3. Dating from the first century A.D., this Roman intaglio $(8 \times 6.4 \times 3.5$ mmi; impression shown in inset) has been carved from emerald that undoubtedly came from Egyptian mines. From the collection of the I. Paul Getty Museum, Malibu, CA; photos by Ellen Rosenbery.

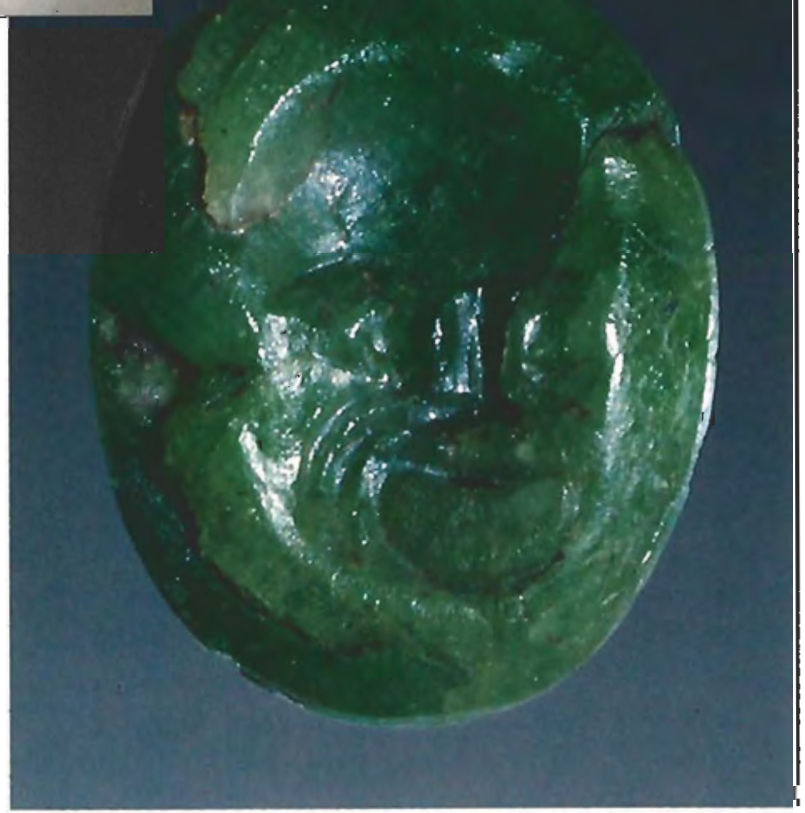

\section{HISTORICAL BACKGROUND}

With the exception of one bead from Nubia dating to predynastic times, the beryls that have survived in Egyptian jewelry date from the Graeco-Roman Period (332 B.C. 395 A.D.; again, see figure 1) and later (Aldred, 1978; Andrews, 1991). In the earliest-Hellenistic-part of this period, one of the important innovations in jewelry was the use of color. Among the stones favored by the Greeks were emeralds (Black, 1981).

Emerald also played a role in the jewelry of imperial Rome, and it is believed that the emeralds discovered in the ruins of Pompeii and Herculaneum, two Italian towns destroyed by the enuption of $\mathrm{Mt}$. Vesuvius in 79 A.D., came from upper Egypt (Rogers and Beard, 1947). Among the treasures found in Ponpeii, and now in the National Museum in Naples, is a gold mesh necklace set with mother-of-pearl and emeralds (Gregorietti, 1969). The emeralds clearly exhibit their natural, hexagonal prismatic form, which is typical of Egyptian emeralds used in ancient jewelry.

By the end of the Roman Empire, there was significant use of gemstones in jewelry, especially emeralds from the Egyptian mines. Among the Roman jewelry in the collections of the British Museum is a necklace from the second century A.D., which consists of gold links with cut-out patterns alternating with prismatic emerald crystals. Such Roman jewelry is also found in the archeological record of Carthage, in what is now Tunisia in North Africa. One example is a third-century A.D. emerald-inlaid hair ornament (Tait, 1987).

Occasionally, emeralds were engraved in Roman times for use as ring stones (Gregorietti, 1969). A firstcentury A.D. oval intaglio that is now in the J. Paul Getty Museum shows an unbearded comic mask (Spier, 1992; figure 3). What is described as one of the best examples of a carved emerald (Middleton, 1891) is a cameo of Medusa's head, cut from a large stone around the time of Emperor Hadrian (76-138 A.D.).

Emeralds are also featured in the jewelry history of Roman Britain. Among the items from the Late Roman Thetford Treasure (all dating to the late fourth century A.D.; Caygill, 1985) is a gold ring with a large bezel that is set with an amethyst in the center and surrounded by alternating garnets and emeralds. Still later, Byzantine jewelry from Egypt, which dates to circa 600 A.D., includes a gold necklace and earrings, all set with emerald crystals, sapphires, and pearls (Tait, 1987). It might reasonably be argued that the prismatic emeralds in a talisman that was buried with Emperor Charlemagne in 814 A.D. were also of Egyptian origin (Black, 1981). Emeralds were used 


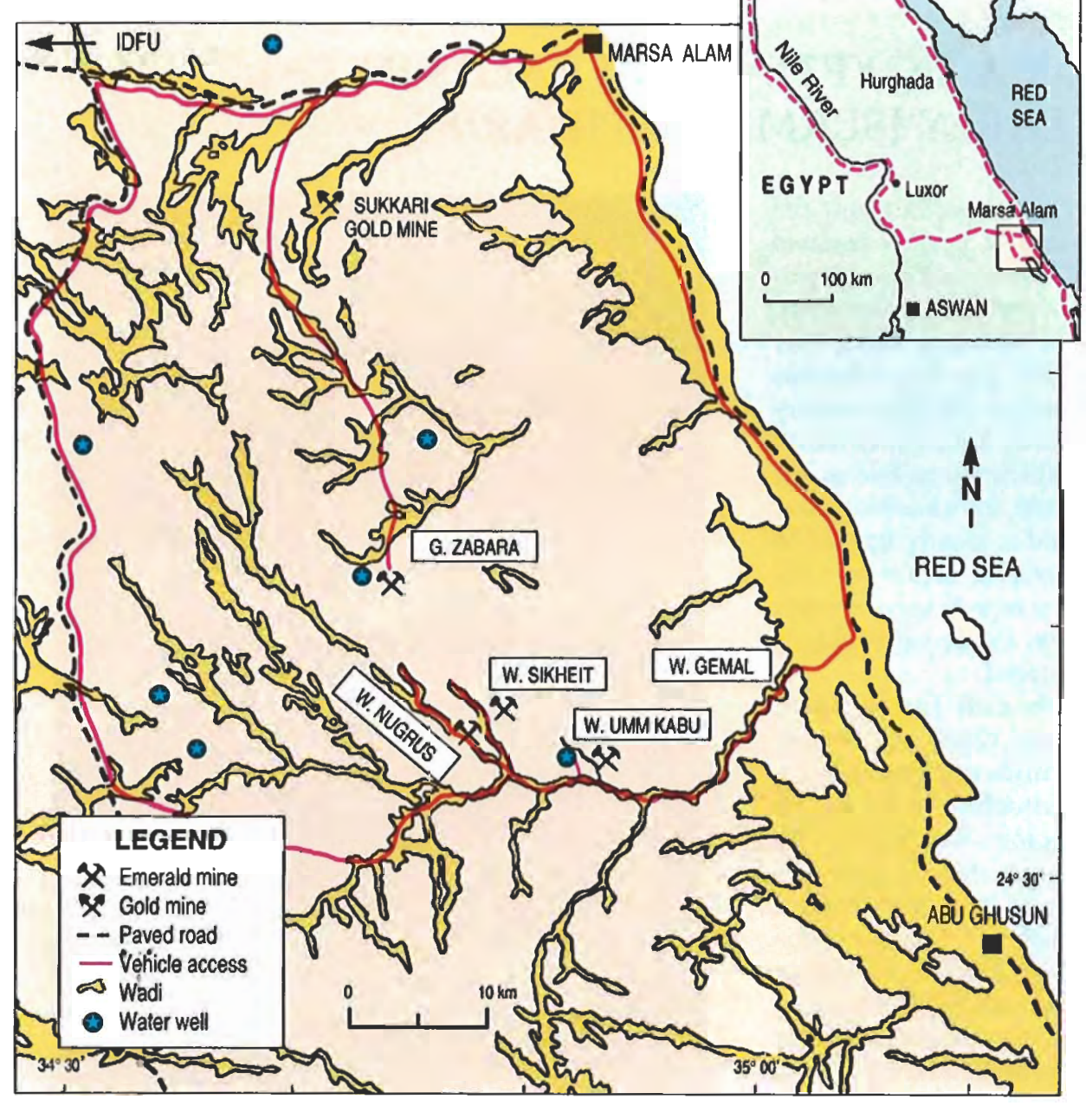

Figure 4. The emeraldbearing province of upper Egypt lies in the hills inland from the coast of the Red Sea. From Cairo, the mines are most easily reached by vehicle via the paved highway that runs along the coast to the small port community of Marsa Alam (see inset). The primary route to the Sikheit, Nugrus, and Umm Kabu localities is through Wadi Gemal, a narrow, simuous wadi that cuts through the Red Sea Hills to the coast. The most direct route to Gebel Zabara is via a desert track that heads south from the paved road between Marsa Alam and Idfu, past the ancient Sukkari gold mine. A guide is essential to find any of the workings. Passage south of Marsa Alam requires a military permit. extensively in the early Islamic cultures as well. In fact, a number of treatises discussing the value of emeralds have been written in Arabic (see box A).

Although many fine accounts of the historic record of emerald mining in Egypt have been published, exactly when these deposits were first exploited remains a mystery. An excellent review is provided by John Sinkankas (1981). According to Sinkankas, there is some evidence suggesting that emeralds were being mined in upper Egypt as early as the 12th Dynasty (2000-1788 B.C.). However, most historians agree only that the emerald deposits were extensively exploited from 330 B.C. (during the Graeco-Roman period) until 1237 A.D. (during the reign of Sultan alKamill.

The emerald mines may have been worked sporadically after this date, but we know of no written record of such activities. By approximately 1740 , the emerald mines had been abandoned. Their location was virtually unlknown until their rediscovery by French explorer Frédéric Cailliaud in 1816 (Sinkankas, 1981).

From 1816 to 1928 , various attempts were made to exploit the emerald deposits commercially. An interesting account of one of these-an expedition mounted to assess the economic feasibility of the deposits for Streeter and Company, London jewelerswas reported by D. A. MacAlister (1900). All of these attempts, however, ultimately were unsuccessful. In fact, there has been no successful commercial mining of the Egyptian deposits in modern times.

Although some general geologic information of value was acquired during this period, more detailed geologic data were obtained later through extensive study and subsequent reporting by Hume (1934), Basta and Zaki (1961), and Hassan and El-Shatoury (1976). An extensive geologic analysis of the Nugrus and Zabara areas was published by Soliman (1986). Most recently, a detailed account of beryllium mineralization in Egypt was published by Hussein (1990). Geologic studies of the area are currently being conducted by the Egyptian Geological Survey and Mining Authority (EGSMA), to assess the gem and mineral resources (Rohr, 1990).

\section{LOCATION AND ACCESS}

The mines are best reached from the small port community of Marsa Alam (see figure 4). The distance from Cairo to Marsa Alam is around $700 \mathrm{~km} 1430$ 


\section{BOX A: EGYPTIAN EMERALDS IN EARLY ISLAMIC LAPIDARIES}

The main textual sources of information about the ancient and medieval workings of Egypt's emerald mines are the lapidaries-books describing the perceived properties of gemstones and related materials. These range from the earliest surviving treatise by Theophrastos (written ca. 315 B.C.), to Pliny's famous Natural History (written in Italy in the first century A.D.l, to the medieval English and Continental European treatises, some of which are as late as the 16 th century. However, specific information about Egyptian emeralds is sparse and is mostly limited to vague descriptions of the geographic area where the mines were located. For more comprehensive sources we must turn, not surprisingly, to the early Islamic lapidaries, of which there are several.

The value of emeralds in the early Islamic period is discussed by Al-Biruni (d. ca. I050), in his great work about gemstones and mineralogy Kitab alDiomahir fi Ma'rifat al-Diowahir [Book of the Manifold Knowledge of Precious Stones]; by AlAkfani (d. I348), in his Kitab Irshad al-Kasid [Treatise on Precious Stones]; and, to a lesser extent, by several other writers cited by Wiedemann in his Uber den Wert von Edelsteinen bei den Muslimen [Concerning the Value of Gemstones by the Muslims] (Strasburg, 1911). However, most relevant to our subject is the chapter on emeralds attributed to Ahmad Al-Tifashi (d. 1253).

The translation below was made by Nahla Nassar using the Arabic text printed in 1818 in Florence titled Kitab Azhar al-Afkar fi Jawahir alAhjar / Fior di Pensieri sulle Pietre Preciose di Ahmed Teifascite [Flowers of Thoughts on Precious Stones from Ahmad Al-Tifashil ledited and translated from Arabic into Italian by Antonio Raineri\}.

\section{CHAPTER III: EMERALDS}

FORMATION: Pliny the Elder mentioned that emeralds are essentially rubies; as they were going through the process of formation, they were red all over. The red color deepened and became more dense, so that it acquired a blackness, and they became azure in color. The intensity and harshness of the dryness forced the blue color to be concentrated in the center; the pure redness rose to the surface and became yellow. Thus

mi.) along the coastal highway, about nine hours.

The mines are located in the Red Sea Hills some $40-60 \mathrm{~km}$ southwest of Marsa Alam. Access is by four-wheel-drive vehicle along a complex system of narrow, sandy-bottomed, dry river beds, or washes, called wadis. These wadis often wind around the

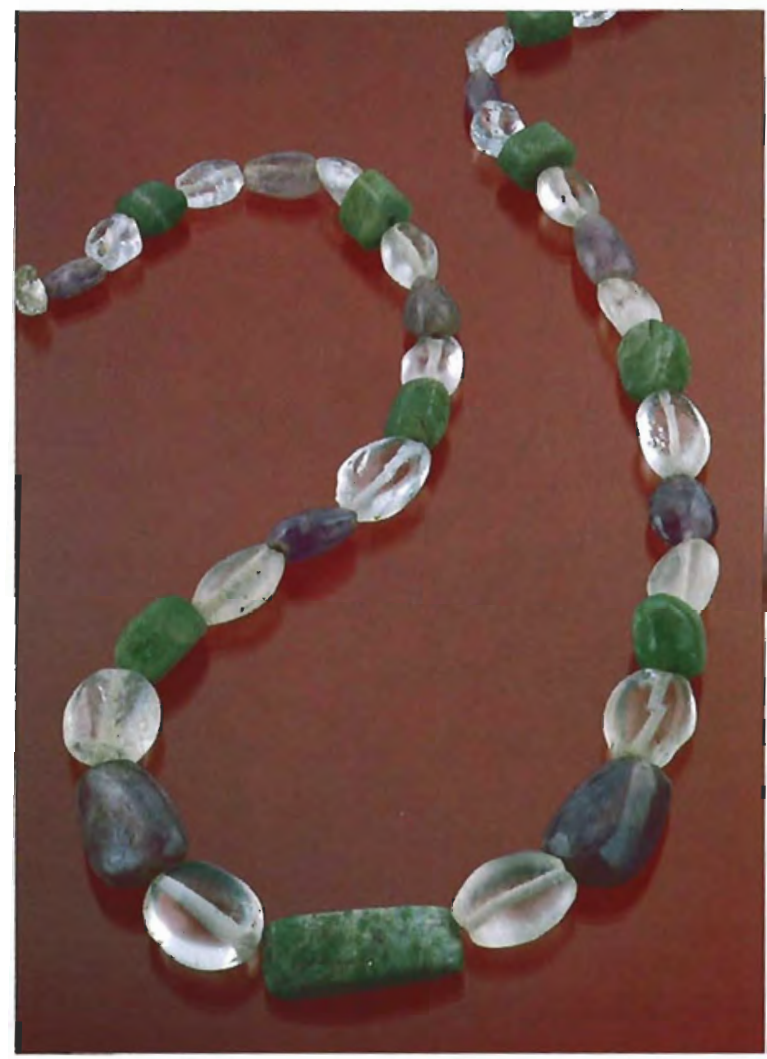

Figure A-1. This reassembled strand of emerald crystals with amethyst and colorless quartz beads is typical of early Islamic jewelry. Note that the large emerald at the bottom center is $27.69 \times 12.27 \mathrm{~mm}$. Courlesy of Derek Content, Inc., Houlton, Maine; photo by Shane F. McClure.

the surface became yellow and the center blue. As the heat increased, the two colors were cooked and mixed together, and both the surface and the center became green...

MINES WHERE IT IS FORMED: Emeralds are formed in the bordering regions between Egypt and the Sudan. Behind Aswan is a long mountain where pieces of emeralds are mined. The head miner in Egypt,

mountains in a complex maze and are subject to dangerous flash flooding. The localities where emeralds have been mined are named after prominent gebels (hills) and associated wadis in the area, namely, Gebel Zabara, Gebel Sikheit, Wadi Nugrus, and Wadi Umm Kabu. There are other known occurrences of emerald in 
appointed in charge of this mine by the Sultan Iprobably Ayyubid Sultan Al-Malik al-Kamil, d. 1238|, said that the first emerald minerals that appear are known as talf; these are black stones that change into golden pyrite when heated. If one mines deeper, one comes across a loose soft red soil in which emeralds are found. Those which are found in the soil are known as fass ["a stone for a ring"]; those which are found still attached to a vein are known as qasab ["a longer stone for jewels"], in the language of jewelers and mineralogists.

GOOD AND BAD VARIETIES: There are four varieties of emeralds: al-Dhubabi, al-Rihani, al-Silqi and alSabouni. The most precious and valuable, and the most superior in all its qualities, is al-Dhubabi. This is a very dark green, untainted by any other color; it is of good pigment and clarity. It was called Dhubabi in relation to the flies [Ar. dhubab] that are found on roses in springtime. These flies are of the purest and most intense green hues. Al-Rihani is of a lighter green color, similar to the color of sweet basil [Ocinum basilicum, Ar. rihan]; the Silqi is the same color as green chard [Ar. silq]; the Sabouni, which is beneath it in quality, is the color of soap [Ar. saboun]. We have already mentioned that the Dhubabi is the best variety in clarity and brilliancy, and the most beautiful. :

IMPERFECTIONS ASSOCIATED WITH EMERALDS: One of the greatest shortcomings of emeralds is the variation in color between stones mined in different places. This applies to all varieties, including alDhubabi. Another is unevenness in shape; this is common in emeralds, rubies, sapphires and all other gemstones. An imperfection inherent in emeralds is cracking: these are concealed cracks that appear in the stones.

CHARACTERISTICS AND BENEFITS: Dhubabi emeralds have a very important characteristic which is particular to this variety, and is used to test real from fake specimens. If a snake looks upon a real Dhubabi emerald, and lays its eyes on it, they will burst on the spot. Ahmad Al-Tifashi said: "I used to come across this characteristic of emeralds in books on gemstones, so I tried it myself. I hired a snake gatherer to hunt a snake. I placed the snake in a basin. I took an arrow and placed a piece of wax on its tip; to that I

this region, such as at Unm Harba and Umm el Dabaa (Sinkankas, 1981), which we did not have time to visit. To reach the emerald localities, a local guide is essential and can be hired (as we did) through the EGSMA office in Marsa Alam. Military permits to travel to the area must be obtained in Cairo. stuck a piece of pure Dhubabi, and put it near the snake's eyes. At first, the snake persisted in moving towards the emerald with a forceful movement that showed a desire to get out of the basin. When the stone was brought even nearer to its eyes, I heard a gentle crackling, and saw that the eyes of the snake had melted and were clearly protruding. ..."

Other characteristics are softness, easy decomposition and lightness in weight; it is also smooth and polished. A beneficial characteristic of emeralds is driving weariness of the eye away from anyone who looks intently upon them. The best Dhubabi will also protect anyone who wears it in a necklace or a ring from epilepsy, especially if it is worn before the oncoming of the disease. Another characteristic is that if it is given in drink to someone who has been bitten or poisoned, it will save him from death. It is also beneficial for excessive discharge of blood; or dysentery if worn on a spot above the liver, and stomach aches if worn above the stomach. It will also prevent poisonous animals from coming near anyone who wears it, or a place where it is found. It helps in difficult births. Another of its characteristics is that devils do not come near anyone who carries it, and will flee the place where it is found. A property of emeralds is that their color intensifies if they are mounted onto a backing.

VALUE AND PRICE: It should be noted that all the above mentioned characteristics belong exclusively to al-Dhubabi emeralds, and not to any of the other varieties. It is for this reason that the price for this variety is high. ... The price increases with the weight of the stone and the presence of the above mentioned descriptions. But the price of a smaller stone does not depreciate as much as small stones of other varieties because of the nobility of this gem and the greatness of its qualities, and the fact that they are more so in a larger stone. Other varieties have no value whatsoever.

[Although, the author adds] ... Al-Tifashi told that he once bought a Rihani emerald from a merchant; after cutting and polishing, it weighed twelve mithqals. He had paid 1,000 dirhams for the uncut stone. Later he took it to the Sultan al-Malik al-Kamil when he was in Damascus, where it was valued at 30,000 dirhams cash; but it was worth much more.

Derek J. Content Houlton, Maine

\section{CARTOGRAPHIC PROCESS}

To accurately navigate the remote labyrinth of canyonlike wadis and produce reliable maps of the mine locations, we used surface geologic maps and satellite imagery of the region in conjunction with a Global Positioning System (GPS). This pocket-calculator- 


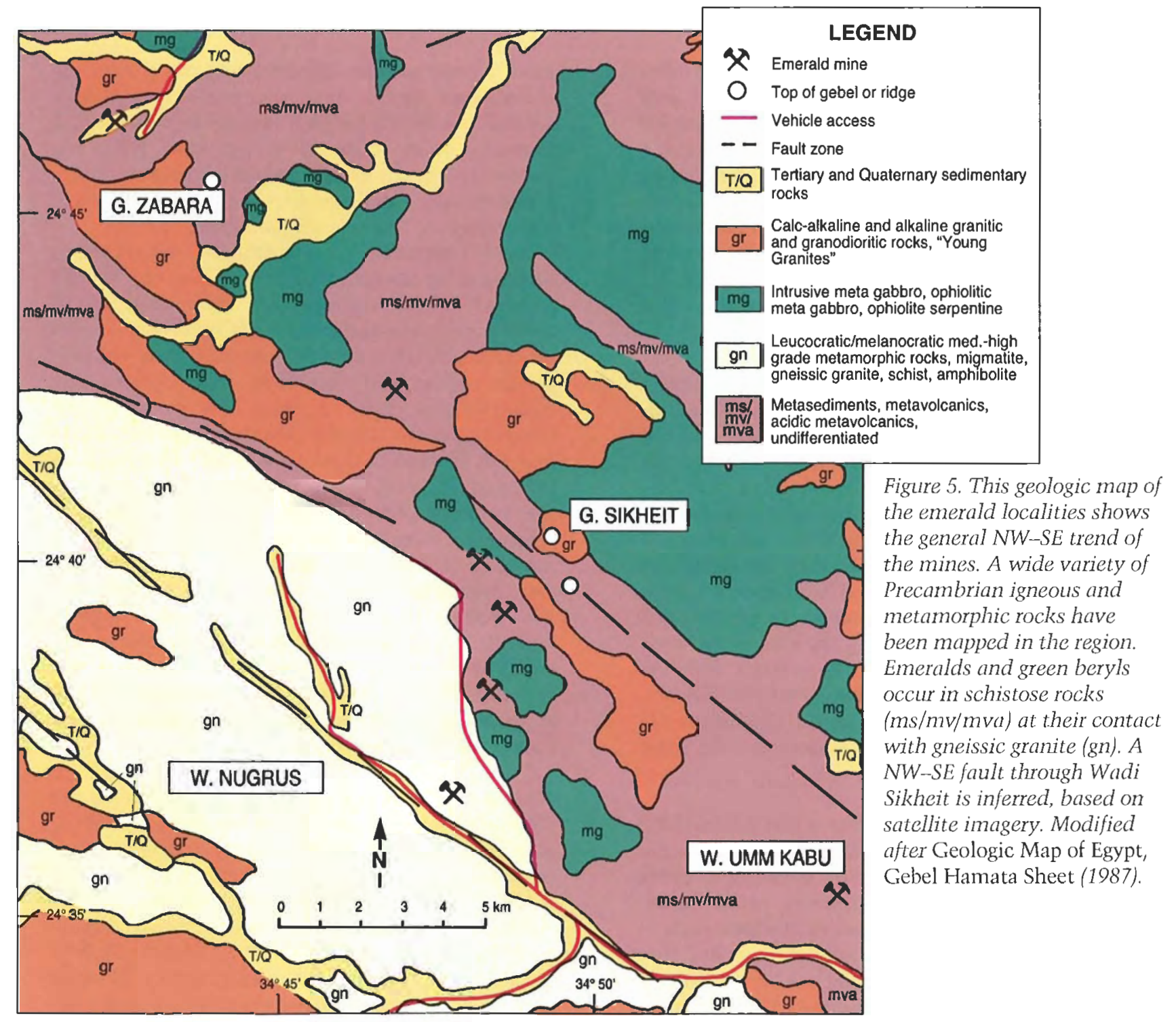

sized, fully portable, battery-operated electronic device provides access to a radio-navigation system operated by the U.S. Department of Defense. Now available from several manufacturers, the GPS allows a user on the ground to triangulate his/her position anywhere in the world by receiving radio signals from satellites orbiting the Earth.

In the Red Sea Hills environment, the twisting nature and steep walls of the wadis, which often extend hundreds of meters above the canyon floor, make dead-reckoning navigation impossible and measurements with other instruments too slow and impractical. With the GPS device, the coordinates of specific points on the ground were recorded in seconds to within $100 \mathrm{~m}$ laterally and were later plotted to reconstruct the maps of the mines shown here. In addition, this invaluable instrument helped the authors find their way back to base camp at night, when all recognizable markers had disappeared in darkness.

\section{GEOLOGY AND OCCURRENCE OF THE EMERALD DEPOSITS}

A comprehensive review of previously published work on the geology of the emerald mines of upper Egypt is beyond the scope of this article, and the reader is referred to the work of Basta and Zaki (1961), Hassan and El-Shatoury (1976), Soliman (1986), and Hussein (1990), for further details. The following overview is a summary of the geologic setting of the emerald deposits at the localities that were visited: Zabara, Sikheit, Nugrus, and Unm Kabu.

A wide variety of igneous and metamorphic rock types have been mapped in the region (figure 5). Basement rocks consist of metasediments and 
metavolcanics (designated $\mathrm{ms} / \mathrm{mv} / \mathrm{mva}$ in figure 5) intruded by granites (Hassan and El-Shatoury, 1976). The emerald deposits of upper Egypt occur within a northwest-southeast trending belt of emerald-bearing schistose rocks that extends for some $45 \mathrm{~km}$ from Gebel Zabara in the northwest to Wadi Umm Kabu in the southeast.

Beryl mineralization is associated with the intrusive contact between a gneissic biotite granite and overlying mica schists (Soliman, 1986). The emeralds and other beryls occur as crystals in biotite schists, biotite-actinolite schists, and biotite-tourmaline schists along this contact, as well as in the quartz veins and pegmatite dikes that commonly cut the emerald-bearing zones in these mica schists. The ancient emerald mines were located where stream erosion had exposed a concentration of emerald along the contact zone and where emerald fragments were abundant in the alluvial deposits of the resultant wadi. It appears that most such concentrations in the region were found and worked long ago, with little left behind for today's collectors.

The linear distribution of beryl mineralization in the region, als indicated by the NW-SE linear distribution of the emerald mines, is generally attributed to the presence of a NW-SE trending deep-seated tectonic zone of Precambrian age. Soliman (1986) speculated that the beryl mineralization is due to pneumatolytic-hydrothermal processes associated with the episodic emplacement of granites during the Precambrian along this NW-SE trending deep-seated tectonic zone. Further speculations on beryl mineralization are given in Hassan and El-Shatoury (1976) and Hussein (1990).

\section{ZABARA}

The Gem-Bearing Deposits. The geology of the beryl occurrences in the Zabara area has been described in detail by Basta and Zaki (1961) and Hassan and ElShatoury (1976). A locality map of the ancient mined areas that were visited is shown in figure 6 . Emerald and green beryl were mined from schistose rocks at their contact with the underlying gneissic granite. The contact is commonly obscured where it has been covered by talus from the steep canyon walls. However, the contact is exposed on both sides of the narrow wadi, and there are numerous shafts along its entire length. The contact plunges below ground level to the northeast, where Wadi Zabara joins a larger, unnamed wadi (figure 7). Numerous quartz veins and fractures cut across the schists and underlying gneissic granites. Mica schists along the contact at some of

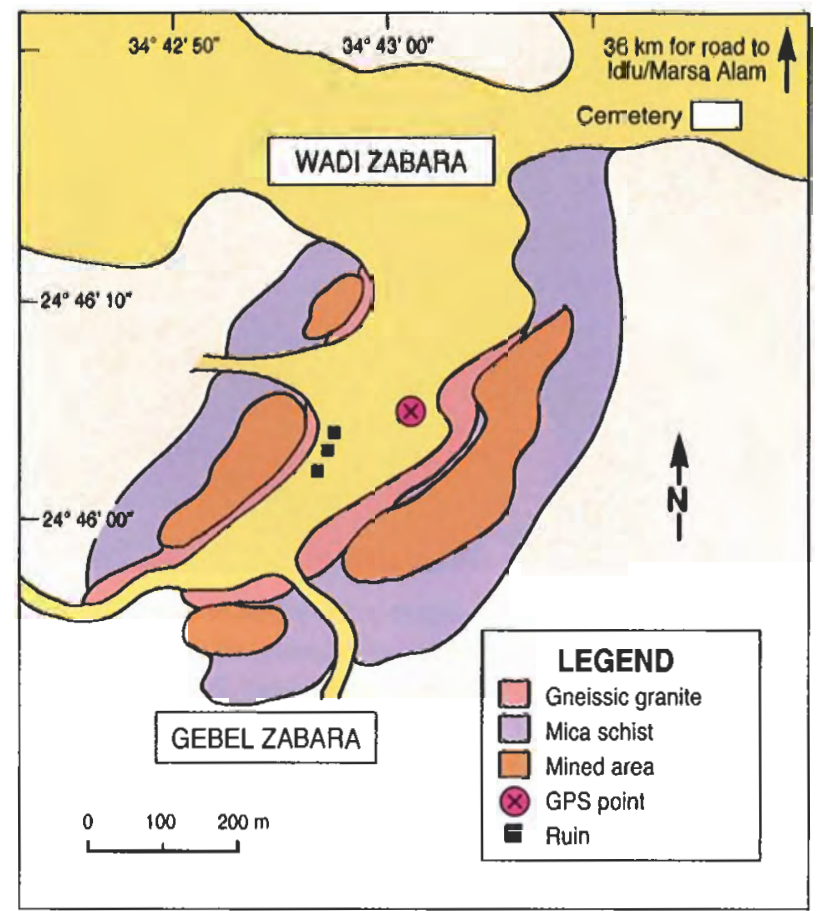

Figure 6. This sketch map of the emerald mines near Gebel Zabara was constructed using GPS navigation. Gneissic granite is exposed near the floor of the wadi. The emeralds occur in overlying mica schists on both walls.

the mines contained some beryl crystals; however, there were no obvious mappable zones of mica schists with abundant beryl mineralization. Rather, it appears that beryl mineralization occurred in limited, discontinuous zones along the contact. Fragments of emerald and green beryl were also recovered from the tailings associated with the mines and from alluvial gravels in the floor of the narrow wadi.

Mine Workings. Simple but extensive mine shafts have been sunk below the workings into the schistgneissic granite contact on both sides of the wadi; we entered workings on the north side. Several near-vertical shafts (up to $15 \mathrm{~m}$ [approximately $50 \mathrm{ft}$.] deep) sunk along the contact here connected at depth to a large area where rooms with pillars had been created to facilitate removal of the mica schists (figure 8). The miners probably used hand tools to remove the ore, which they then carried to the entrance of the mine, at which point the material was broken and worked for emerald. There was no indication that a mappable emerald-bearing zone or reef had been systematically mined. Nor was there evidence of recent 


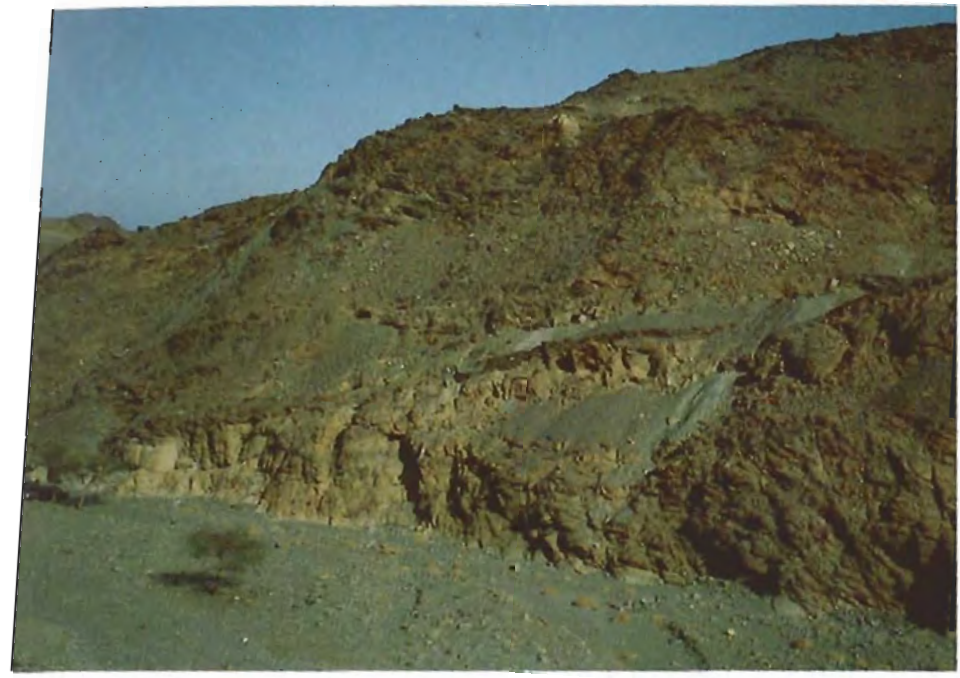

Figure 7. The intrusive contact and emerald workings can be seen here, looking northeast, in one wall of Wadi Zabara. The true strike and dip of the contact are unknown. The contact plunges to the northeast below ground level at the entrance to the wadi (to the left on the photograph). Emerald workings occur above this contact, with the mine tailings extending from below the workings and down to the wadi floor. Note the cars on the far left for scale. Photo by Robert lennings.

mining in situ, although shallow pits with unweathered dirt in the mine tailings and alluvial gravels of the wadi floor indicate recent activity.

According to Cairo gem dealer Ali Khorrassany, the Bedouin of the area work the wadi gravels from November to March, when the region receives most of its scant rainfall. When it rains in the desert, there can be substantial flooding in the wadis. This natural process results in a "float," as the floods wash through the wadis carrying huge volumes of sand and gravel. The floods are usually brief and, soon after they subside, the Bedouin visit the wadis that drain the emerald workings to sort through the surface gravels by hand, looking for the green gems.

\section{SIKHEIT AND NUGRUS}

The Gem-Bearing Deposits. The workings along Wadi Sikheit and Wadi Nugrus are near Gebel Sikheit. The geology of the beryl occurrences in the Sikheit/Nugrus localities has been described in detail by MacAlister (1900), Hume (1934), Basta and Zaki (1961), and Hassan and El-Shatoury (1976). MacAlister (1900) sketched one of the more accurate maps ever produced of this locality (shown in figure 9, modified using GPS navigation). Our GPS recording changed the mapped orientation of some wadis and indicated that there is no vehicular connection between Wadi Abu Rushaid and Wadi Sikheit. A geologic map of this locality was pub-

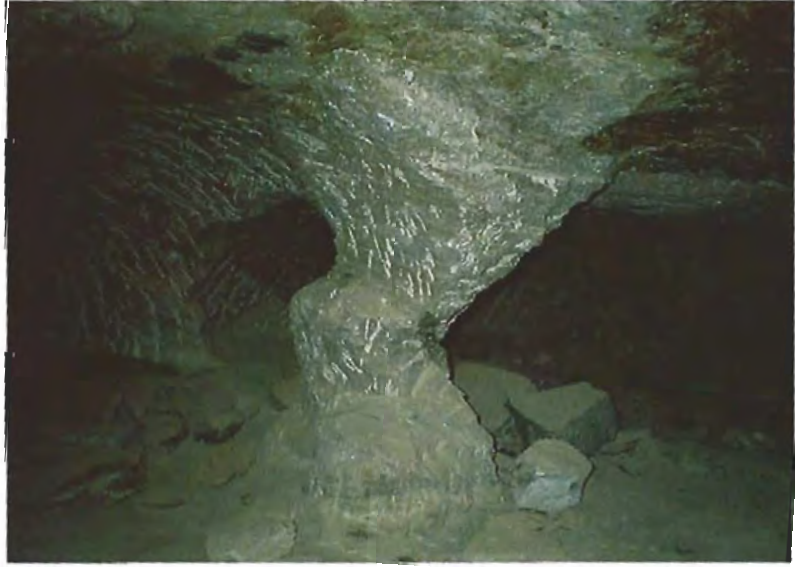

Figure 8. This view is inside one of the mines on the north wall of Wadi Zabara, entered through a near-vertical shaft excavated along the schistgneissic granite contact. Note the chisel marks and the pillar, approximately $1 \mathrm{~m}$ in diameter, left as support. Photo by Robert C. Kammerling.

lished by Hassan and El-Shatoury (1976). Grubessi et al. (1990) published one of the more recent accounts of an excursion to this locality, commenting on the many fine ancient ruins (dwellings and temple) to be seen. The main temple at Wadi Sikheit, carved into the canyon walls, has served as a landmark for many travelers (figure 10). Unfortunately, graffiti has tarnished some of its aesthetic beauty.

The most extensive emerald workings at this locality can be found (1) on the southwest slopes of Gebel Sikheit, along the upper reaches of Wadi Sikheit; (2) midway along Wadi Sikheit, near the temple and associated ruins (both sides of the wadi); and (3) on the northeast side of Wadi Nugrus, near the ruined dwellings. The occurrence of beryl in these two wadis is restricted to the mica schist-gneissic granite contact zone (Hassan and El-Shatoury, 1976). Beryl is concentrated in discontinuous zones in schistose rocks along this contact, and in quartz veins cutting the schists and underlying gneissic granites. As at Zabara, this contact is often obscured by alluvium or by tailings from the numerous mines. In most places, the contact between the beryl-bearing schistose rocks and the underlying gneissic granite is inferred. The berylbearing schists are exposed on the slopes of Gebel Sikheit, and to the southeast along Wadi Sikheit, toward the ruins. According to MacAlister (1900) and Hume (1934), the deposits on the slopes of Gebel Sikheit occur in four bands of mica schist and talc schist. These schists are mapped in fault contact with the gneissic granite in Hume (1934). No new geologic mapping was conducted in this area other than to confirm the rock types and mineral associations that had previously been described. 


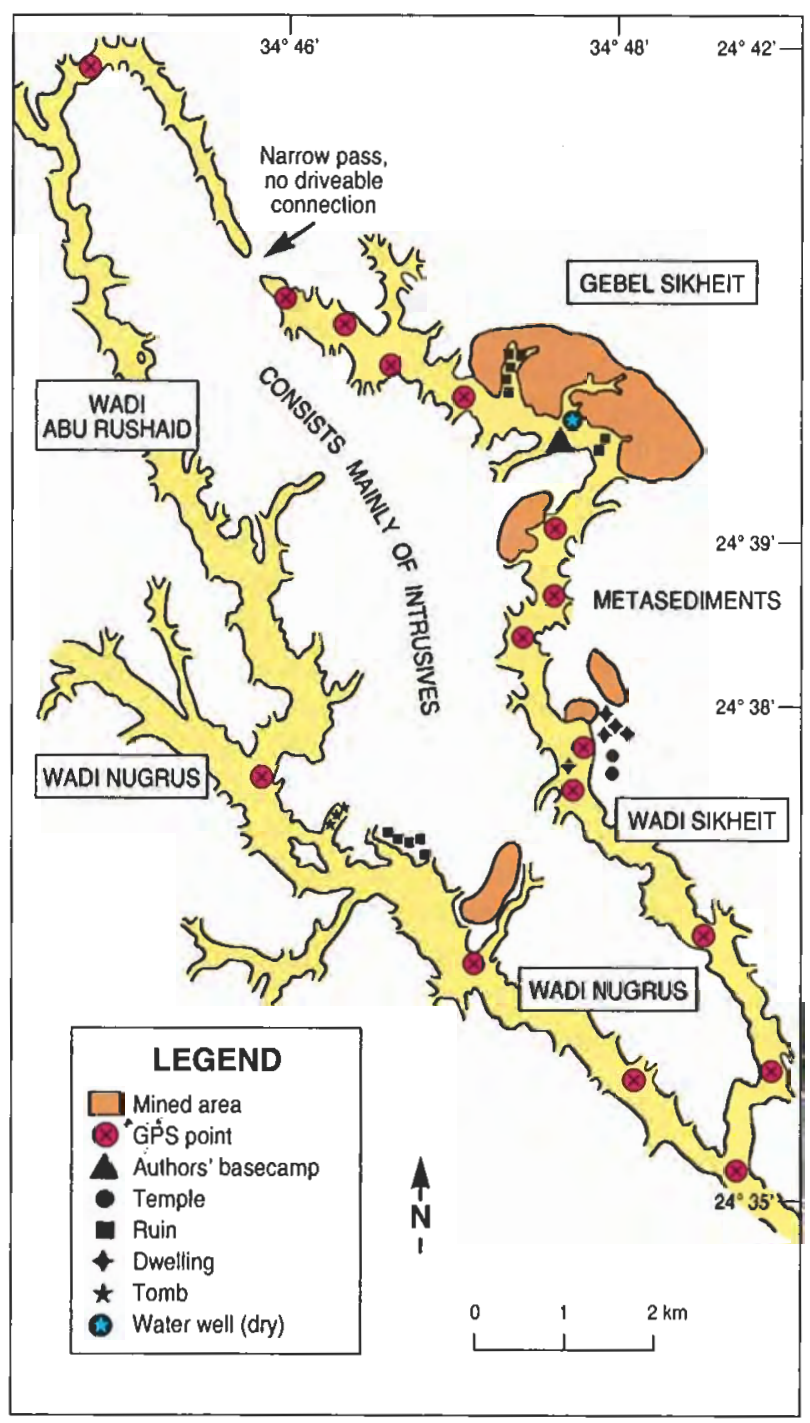

Figure 9. This map of the emerald mines of Wadi Sikheit and Wadi Nugrus is modified from GPS navigation after a sketch map of D. MacAlister (1900). The authors' global positioning survey changed the mapped orientation of some of the wadis and indicated there was no vehicular connection between Wadi Abu Rushaid and Wadi Sikheit.

Mine Workings. The abundance of ancient shafts, adits, and associated mine tailings in the Sikheit/Nugrus localities suggests that this area was extensively worked in the past. Mine shafts and adits occur in groups, probably where stream erosion along the wadis exposed the emerald-bearing rocks. Some groups of mines were worked more than others, as evidenced by their large chambers and interconnected tunnels. The extensive ruins in Wadi Sikheit and Wadi Nugrus also indicate that there was a high level of emerald-mining activity in the past, considerably more than at Zabara.

There is evidence that some of the mines at this

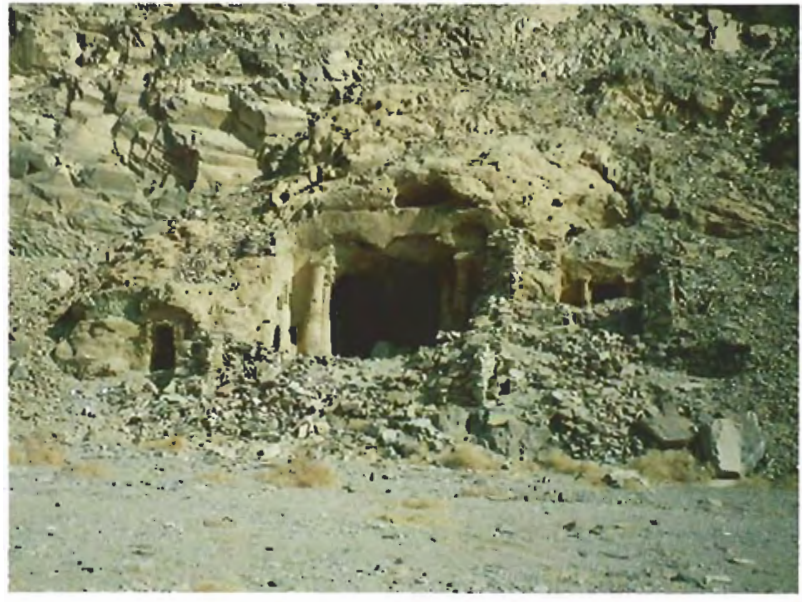

Figure 10. This temple, carved into the canyon wall and dating to Ptolemaic times (circa 300 B.C.), is at the entrance to Wadi Sikheit. It has long served as a landmark for travelers in the region. Photo by Robert C. Kammerling.

locality have been worked in more recent times. Some of the mine shafts and adits at Sikheit are marked with wooden survey stakes, and the entrances to a few of the larger mines are numbered with paint (figure 11). In addition, unweathered tailings piles of limited extent were seen at the entrances to some of the workings along the lower part of Wadi Sikheit. Goat and camel droppings and fire pits indicated that Bedouin camps had been set up relatively recently. However, the small size of the unweathered tailings suggests that recovery has not been systematic. No mines in the area we visited could be considered active.

There is also considerable evidence, in the form

Figure 11. The authors came across some evidence that mines on the slopes of Gebel Sikheit had been worked in more recent times. Note the number painted here at a mine entrance on the southwest. slope of Gebel Sikheit. Photo by Robert Jennings.

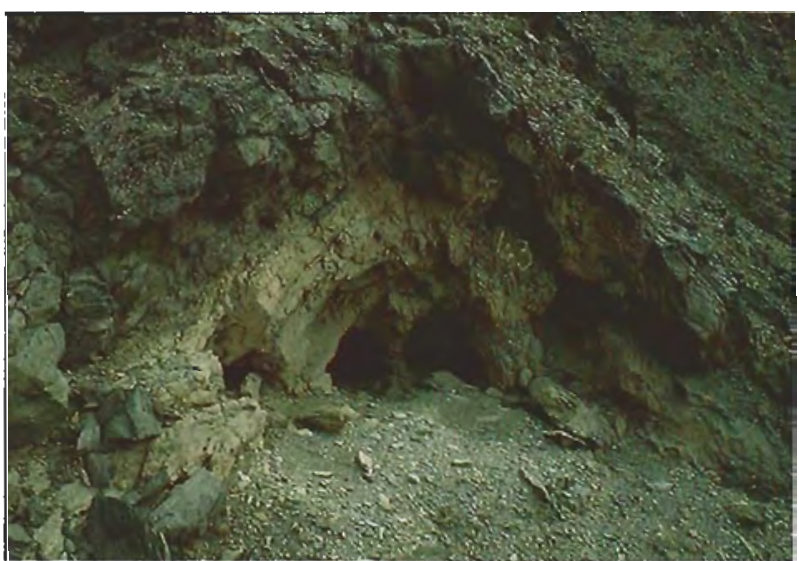




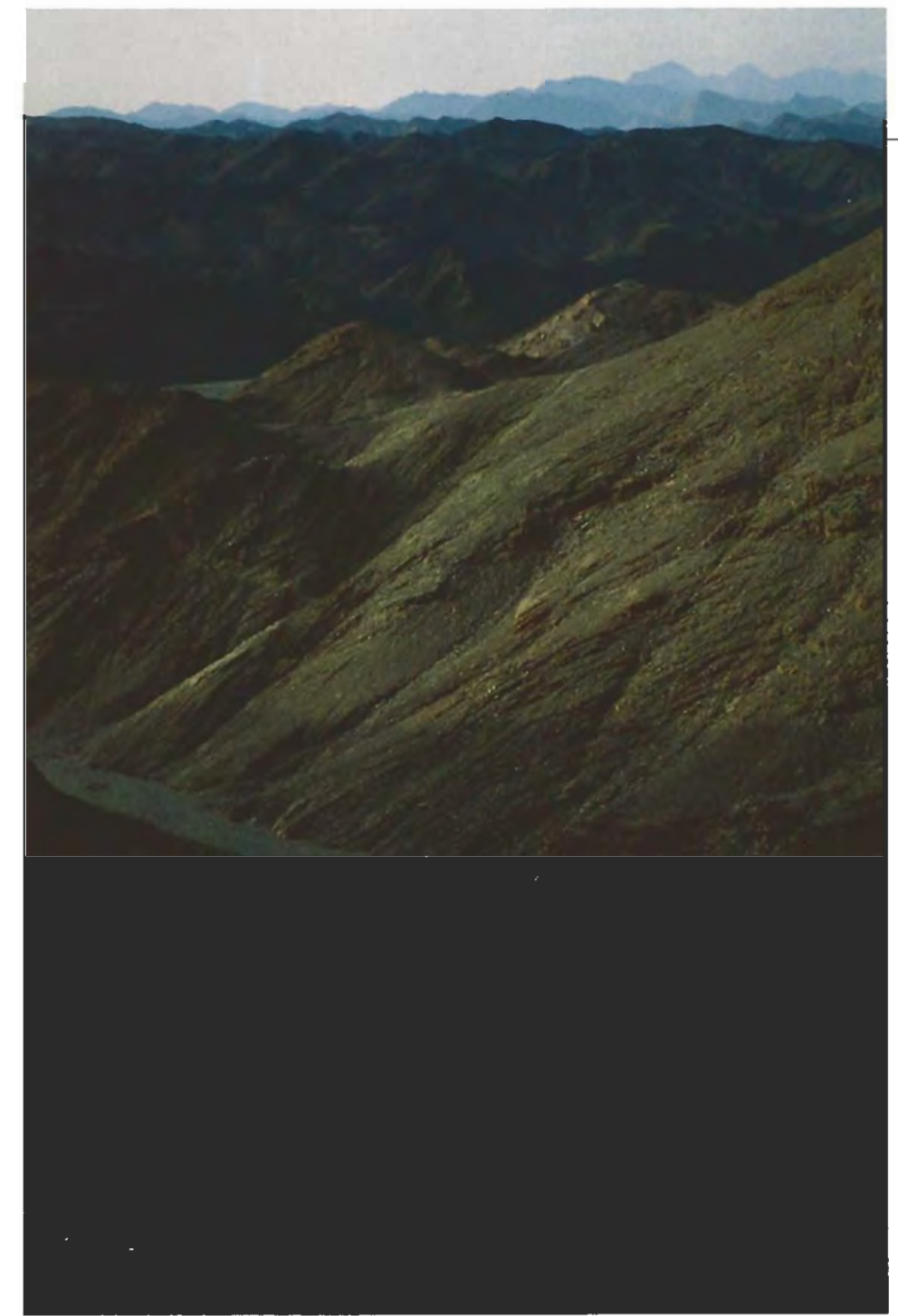

Figure 12. This narrow wadi, just north of Wadi Nugrus and below extensive mine workings on the ridge, provides key drainage for the extensive emerald workings. Such wadis often form narrow, sinuous canyons as they cross the Red Sea Hills. Photo by Robert Jennings.

of abandoned camps and shallow, unweathered diggings, that the gravels that drain the mine tailings are still worked periodically (figure 12).

It is interesting to note that many of the ruins of dwellings at Wadi Sikheit and Wadi Nugrus appear to be situated adjacent to or on mine tailings and cavedin adits. It is possible that the early miners constructed habitats in such proximity to the workings to maintain security.

\section{UMM KABU}

Description of the Gem-Bearing Deposits. The location of the Umm Kabu workings is shown in figure 13. The emerald mines are accessed from two wadis that branch north-northeast from Wadi Gemal. Both of these wadis are extremely narrow $(5-30 \mathrm{~m})$ and sinu- ous, and both contain additional stone ruins near the workings. We noted very recent vehicle tracks on the northern side of the workings, which suggests that vehicular access is possible via another wadi on the north or northeast flank of the mined area.

Very little information has been published on Umm Kabu, although the geology was briefly described by Hume (1934) and by Hassan and ElShatoury (1976), the latter including a geologic sketch map of part of the area. Even so, the workings here are as extensive as those at Sikheit/Nugrus, which suggests that they were once a major source of emerald. The occurrence of beryl at Umm Kabu, as at the other localities, is believed to be due to the emplacement of granites into mica schists (Hassan and El-Shatoury, 1976; Soliman, 1986). There is very little evidence here, however, of this intrusive contact. Cobbles of gneissic granite, white granite, hornblende gneiss, and serpentinite were observed in the alluvial fill of the wadis leading to the emerald workings, as were numerous types of mica schists and beryl. A few small exposures of gneissic granite and white granite were found in the lower reaches of Wadi Umm Kabu. It is assumed that the occurrences of beryl here are indicative of the occurrence of intrusives very close to the surface at this locality.

Abundant fragments of green beryl and emerald were found along both of the narrow wadis that lead to the emerald workings of Umm Kabu. Emerald was found as small (a few millimeters in diameter), loose, hexagonal prisms, as well as single crystals and occasional clusters embedded in quartz and biotite schist. The emeralds embedded in biotite schist seemed to have the best color. Fragments of green beryl and emerald were also found in the tailings piles.

Mine Workings. The ancient mine workings at this locality are considerable, as can be seen by the extensive tailings (figure 14). Most of the shafts are now caved in, but those that are partially open indicate that they were nearly vertical. As at Sikheit and Nugrus, the mine shafts were located to excavate obvious zones of emerald-bearing mica schist.

Piles of cobbed material--emerald and green beryl in quart $z$ and in biotite schist-were seen around the ruins at the entrance to Umm Kabu. The cobbing appeared to be fresh, with no evidence of weathering, which suggests that the material had been transported down the wadis from an active working relatively recently. However, we could not deternine the source of the emeralds. It is possible that cobbing was done on old material.

The footpaths along both of the wadis that lead to 
and across the ancient workings at Umm Kabu are well worn, and there is considerable evidence that Bedouin visit the area frequently with their camels and goats. Several campsites were evident along both wadis and at the ancient mines.

In the few days we walked between the entrances of these two wadis and the ancient emerald workings, we found a few dozen small crystals and crystal fragments of emerald and green beryl. It is possible that these gravels could yield considerable amounts of similar material if they were systematically worked.

Figure 13. The emerald mines of Umm Kabu are accessible only by foot from Wadi Gemal. The two main wadis shown drain the mined area. Abundant emerald fragments were recovered by the authors from alluvial gravels along the entire length of the narrow wadis. This original sketch map was constructed from GPS points recorded in the field at locations shown.

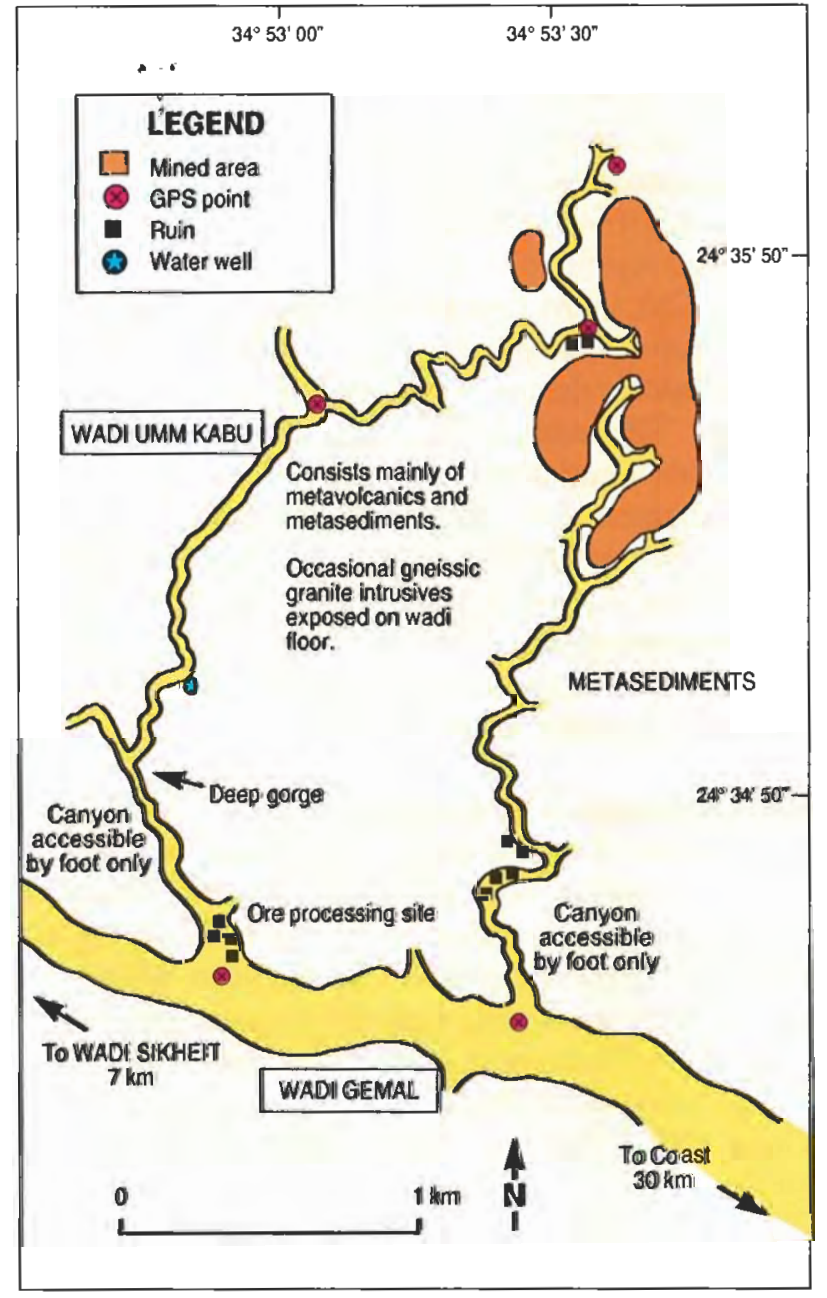

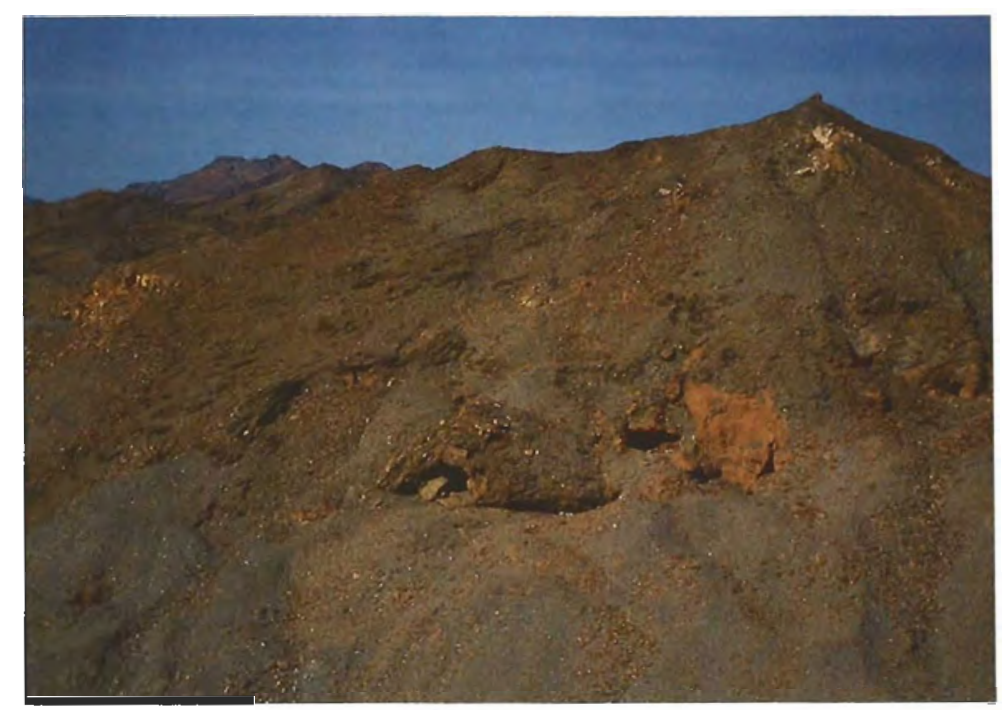

Figure 14. The ancient mine workings at Umm Kabu are considerable, as can be seen from the extensive tailings. Photo by Robert Jennings.

\section{THE CURRENT STATUS OF PRODUCTION}

At the time of the authors' visit, no commercial mining was being carried out on a mining exploitation license issued by the Egyptian Geologic Survey and Mining Authority at any of the localities visited. Recent discussions with merchants in Cairo indicate that EGSMA has awarded an Egyptian firm a twoyear exploration license for the Sikheit region. However, we were unable to obtain official confirmation of this.

It is interesting to note that several exploitation licenses have repoitedly been awarded by the Egyptian government in the last 10-15 years to mine mica in the Zabara region (A. Khorrassany, pers. comm., 1991). EGSMA is currently encouraging individuals to invest in gem mining in the emerald-bearing region, but taxes, interference by local authorities, and, no doubt, the generally low quality of the material have so far discouraged activity. Interest by local investors is also affected by the fact that most Egyptians prefer gold and diamonds for jewelry. To attract foreign investment, EGSMA is currently conducting new studies in this region to evaluate the potential of the gem deposits.

Most gem materials recovered today are by Bedouin who pick through the ancient tailings and material weathered from the host rock and deposited in the wadis. Many are employed by the geologic survey and thus have acquired considerable knowledge of the location of many gems and minerals. Production 
figures are unknown, as none of the emerald-bearing deposits is mined officially.

According to Ahmed Hussein Moustafa of the Zaglool Bazaar in Luxor (pers. comm., 1991), emerald crystals are hand carried to the towns of Idfu and Luxor, where they are sold to merchants for fashioning. Most of the material is not gem quality and, at present, there does not appear to be enough gem-quality emerald to justify much more activity. However, Mr. Moustafa has made a few trips to Idar-Oberstein in Germany to have some of the better-quality material fashioned. Most of the fashioned material has been cut en cabochon and is sold to tourists in Luxor. The Bedouin also bring other gem materials to Idfu and Luxor - such as amazonite, amethyst, chrysoprase, fluorite, and peridot - from the Red Sea Hills surrounding Wadi Gemal.

\section{GEMOLOGICAL AND SPECTROSCOPIC CHARACTERISTICS}

Materials and Methods. Fourteen specimens of emerald and green beryl from Upper Egypt were acquired for the gemological study performed at the GIA Gem Trade Laboratory in Santa Monica, California. These specimens (see, e.g., figure 15), which are from unspecified mining localities in upper Egypt, were obtained from two sources: (1) Ali Khorrassany, who both personally collected rough from the mining areas and acquired specimens from local Bedouin; and (2) Ahmed Hussein Moustafa, who purchased specimens from Bedouin who also reportedly collected them in the mining areas. Thirteen of the specimens are cabochons and range from 0.38 to $17.50 \mathrm{ct}$; the 14th specimen is a 2.28-ct emerald cut. None of the crystal fragments found by the authors on site was large enough or of high enough quality for gemological testing.

The specimens ranged in diaphaneity from translucent to semitransparent, as a result of being moderately to heavily included, and in color from medium-light to dark green. With regard to the latter, it should be noted that Egyptian emeralds are variously described in the literature as ranging from "very pale bluish green or yellowish green to the intense green hue" (Sinkankas, 1981) and as "light-coloured" (Webster, 1983), although darker material has also been reported (again, see box A). Because Egyptian stones are described as often being light toned, the question has arisen as to whether they are properly classified as emeralds rather than green beryls. The staff of the GLA Gem Trade Laboratory determined that, on the basis of color, 12 of the 14 specimens used in the

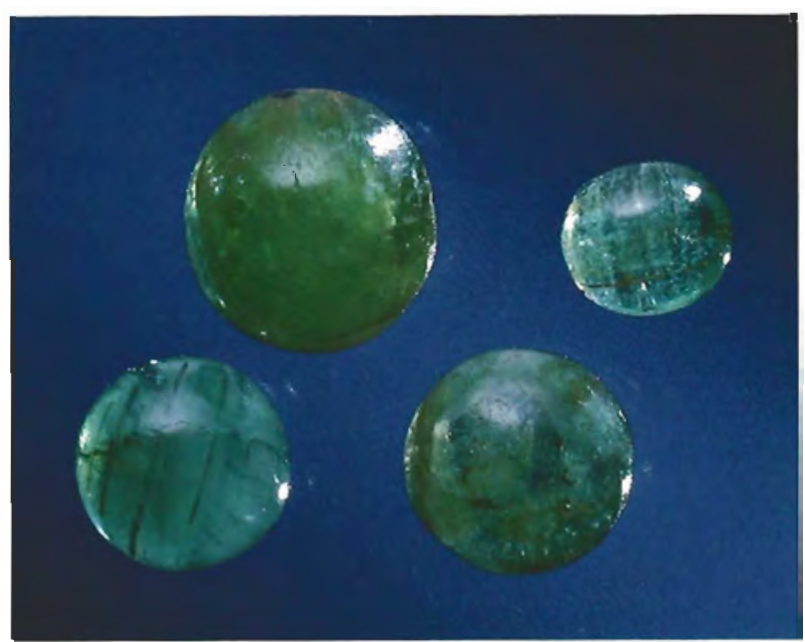

Figure 15. These emerald cabochons $(0.46-1.72 \mathrm{ct})$, used in the gemological investigation, are typical of the Egyptian emeralds/green beryls currently available in limited quantities. Photo $\mathbb{C}$ Tino Hammid and GIA.

gemological study were appropriately called emerald, while the other two qualified as green beryl.

Refractive indices were taken with a Duplex II refractometer; pleochroism was determined with a Polaroid-filter-type dichroscope; specific gravity was measured hydrostatically; microscopic examination used a GIA GEM Instruments Mark VII GemoLite microscope; and spectra were observed with a GIA GEM desk-model unit fitted with a Beck prism spectroscope. The results of gemological testing are reported in table 1 and discussed below.

The chemical composition of five of the samples was determined qualitatively using a Tracor Spectrace 5000 X-ray fluorescence (EDXRF) analysis system. Mid-infrared spectra $(400-4000 \mathrm{~cm}-1)$ of two of the samples were recorded using a Nicolet 60SX Fouriertransform infrared spectrometer.

Refractive Index. Spot readings on the cabochons were 1.57 to 1.58 . The one faceted specimen, on which a flat-facet reading could be obtained, yielded refractive indices of $\mathrm{e}=1.581$ and $\mathrm{o}=1.588$, with a birefringence of 0.007 . These latter values lie between the $1.573-$ 1.580 values previously reported for emeralds mined along the eastem side of Wadi Sikheit, the 1.577-1.585 values reported for stones recovered from the bise of Gebel Sikheit (Basta and Zaki, 1961; Sinkankas, 1981), and the 1.590-1.596 reported for stones from Gebel Zabara by Grubessi et al. (1990). These values are also 
within the documented range for emeralds from numerous other localities (Sinkankas, 1981).

Pleochroism. Although all of the specimens were moderately to highly included, it was possible to resolve their pleochroic colors. The weak to moderate dichroism of yellowish green and bluish green observed in all the stones is consistent with that observed in emeralds from other localities (Sinkankas, 1981).

Ultraviolet Fluorescence. All 14 specimens were inert to short-wave ultraviolet radiation, but the 13 cabochons displayed faint to weak yellowish green luminescence to long-wave U.V. The long-wave reaction may be the result of residual substances (oils?) used to fill surface-reaching fractures (see below). The fluorescence of green beryls and emeralds is known to be variable and, in general, weak (Sinkankas, 1981).

TABLE 1. Gemological characteristics of emeralds and green beryls from upper Egypt. ${ }^{\text {a }}$

\begin{tabular}{|c|c|}
\hline Property *.* & Observations \\
\hline Cokr & Medium-light to dark green \\
\hline Clarity & Transiucent to semitransparent \\
\hline Refractive indices & $\begin{array}{l}1.57 \text { to } 1.58 \text { (spot }^{b} \\
e=1.581, o=1.588^{c}\end{array}$ \\
\hline Birefringence & $0.007^{c}$ \\
\hline Pleochroism & $\begin{array}{l}\text { Weak to moderate dichroism; yellowish } \\
\text { green (ordinary ray) and bluish green } \\
\text { (extraordinary ray) }\end{array}$ \\
\hline \multicolumn{2}{|l|}{ U.V. fluorescence } \\
\hline Long-wave & Inert or faint to weak yellowish green ${ }^{\text {a }}$ \\
\hline Short-wave & Inert \\
\hline $\begin{array}{l}\text { Chelsea filter } \\
\text { reaction }\end{array}$ & $\begin{array}{l}\text { Negative }\{\text { i,e., yellowish green }\} \text { to weak } \\
\text { to moderate pink }\end{array}$ \\
\hline Specific gravity & $2.62-2.73$ \\
\hline $\begin{array}{l}\text { Oplical absorption } \\
\text { spectrum (nm) }\end{array}$ & $\begin{array}{l}\text { Typical "emerald" absorption spectrum } \\
\text { (Liddicoat, 1989). Key features: } 683.5 \text { and } \\
680.5 \text { doublet and lines at } 662 \text { and } 646^{\circ}\end{array}$ \\
\hline Internal features & $\begin{array}{l}\text { Numerous partially healed fractures composed } \\
\text { of two-phase (liquid and gas) inclusions, un- } \\
\text { healed fractures stained with a yellowish brown } \\
\text { substance (limanite?), growth tubes running } \\
\text { parallel to the optic axis (some with yellowish } \\
\text { orown staining), translucent brown tabular inclu- } \\
\text { sions (biotite?), oxidized amphibole "stalks," and } \\
\text { possibly decomposed filling material in surface- } \\
\text { reaching fractures }\end{array}$ \\
\hline \multicolumn{2}{|c|}{$\begin{array}{l}\text { Study sample includes } 13 \text { cabochons and one faceted stone. } \\
\text { "Spot readings determined on } 13 \text { cabochons. } \\
\text { "Flat lacet reading determined on one faceted stone. } \\
\text { "Flurescent reactions possibly due to fracture-filling residues. } \\
\text { The three lightest-colored stones exhibited only two weak absorption } 683.5 \text { and } 680.5 \mathrm{~nm} \text {. }\end{array}$} \\
\hline
\end{tabular}

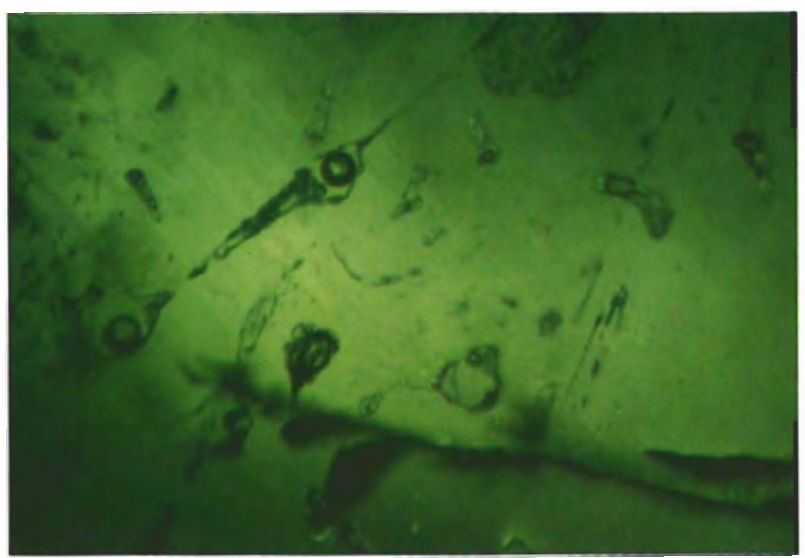

Figure 16. Two-phase fluid inclusions such as these were noted in most of the emeralds and green beryls examined by the authors. Photomicrograph by John I. Koivula; magnified 50×.

Chelsea Filter Reaction. When viewed through the Chelsea color filter, 11 of the specimens gave a "positive" reaction, ranging from weak to moderate pink. The remaining three stones-the three lightest-color specimens-gave a negative (yellowish green) reaction. While emeralds from many localities give a positive (red) reaction to the Chelsea filter, emeralds from India and some African localities also have a negative reaction (Webster, 1983).

Specific Gravity. The range of S.G. values is consistent with those for emeralds from many localities (Sinkankas, 1981). The variation in S.G. values may be at least partly explained by the differing degree to which individual stones are fractured and/or contain fluid and mineral inclusions. Previous documentations of Egyptian emeralds report a specific gravity of 2.75 (Basta and Zaki, 1961; Sinkankas, 1981; Grubessi et al., 1990).

Magnification. All of the stones contained numerous partially healed fractures, which were composed of two-phase, liquid and gas, inclusions (figure 16). Several of the stones also had unhealed fractures stained by a yellowish brown substance, possibly limonite. Another distinctive feature common to most of these specimens was the presence of growth tubes running parallel to the c-axis, some of which also exhibited yellowish brown staining (figure 17). Parallel growth tubes in emerald have been reported from several localities, including Brazil (Gübelin and Koivula, 1986) and Pakistan (Gübelin, 1982). 


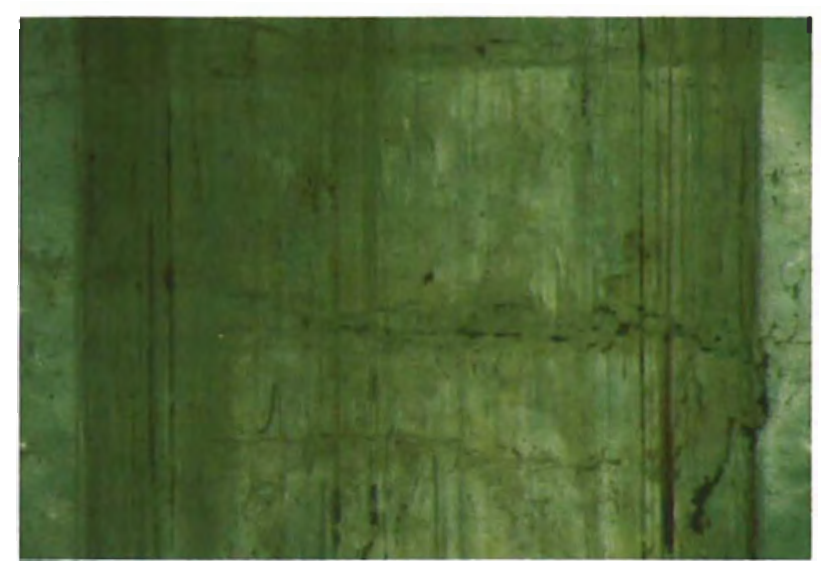

Figure 17. Growth tubes running parallel to the caxis were also noted in some of the specimens used in this study. Some, like those shown here, contained what appears to be epigenetic limonite staining. Photomicrograph by John I. Koivula; magnified $15 \times$.

Six of the specimens contained translucent brown tabular inclusions that resemble biotite (figure 18). Biotite in emerald is associated with metamorphic deposits such as those in the Ural Mountains of Russia (Schmetzer et al., 1991), Austria, India, Mozambique, Norway, Zimbabwe, and Brazil /Gübelin and Koivula, 1986). In addition, one of the specimens had a cluster of oxidized amphibole "stalks" (figure 19), an internal feature that has also been observed in emeralds from the Habach Valley, Austria, and from Sverdlovsk in the Ural Mountains (Gübelin and Koivula, 1986). Given that the inclusions observed in these specimens also occur in emeralds from numerous other localities, we believe that Egyptian emeralds and green beryls cannot be conclusively identified as to their locality on the basis of these characteristics.

It was interesting to note that some of the stones contained what appears to be decomposed filling material in their surface-reaching fractures. It is possible that the fractures were treated with oil to enhance the apparent clarity. With time, the oil could decompose, leaving behind a dry residue. As suggested above, this could explain the yellowish green long-wave U.V. fluorescence noted in some of the stones. The historic use of oil to treat emeralds in Egypt has been documented. Schneider (1892) quotes Schehab ed-din Abul Abbas Achmed from his work Mesa-Lek Al-Absar, written in the Middle Ages: "When an emerald is found it is thrown into hot oil, then in wood shavings and wrapped in linen or some other material." One of the cabochons had a green filling material in surfacereaching fractures.

Absorption Spectra. Eleven of the specimens exhibited a typical "emerald" absorption spectrum (Liddicoat,

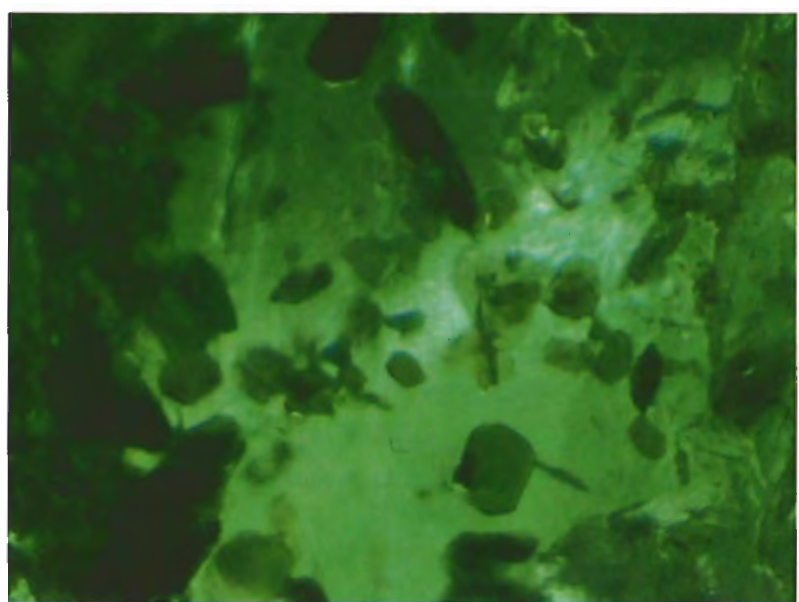

Figure 18. Translucent, brown, tabular inclusions were another internal feature noted in the Egyptian emeralds/green beryls. Photomicrograph by John I. Koivula; magnified $30 x$.

1989|, key features of which are a doublet at 683.5 and $680.5 \mathrm{~nm}$, as well as absorption lines at 662 and $646 \mathrm{~nm}$. The three lightest-color specimens, howev$\mathrm{er}$, had only two weak absorption lines at $683.5 \mathrm{~nm}$ and $680.5 \mathrm{~nm}$. This type of spectrum is typical of lighter green beryls such as Brazilian stones of pegmatitic origin (Liddicoat, 1989).

EDXRF and U.V.-Visible Analyses. Besides the expected aluminum and silicon, EDXRF analysis revealed the presence of chromium, vanadium, and iron in varying amounts, with the XRF peak for iron being greater or equal in height to the XRF peak for chromium, and

Figure 19. Oxidized amphibole "stalks," typical of emeralds from such localities as the Ural Mountains of Russia and the Habachtal Valley, Austria, were seen in one of the Egyptian specimens studied. Photomicrograph by John I. Koivula; magnified $25 \times$.

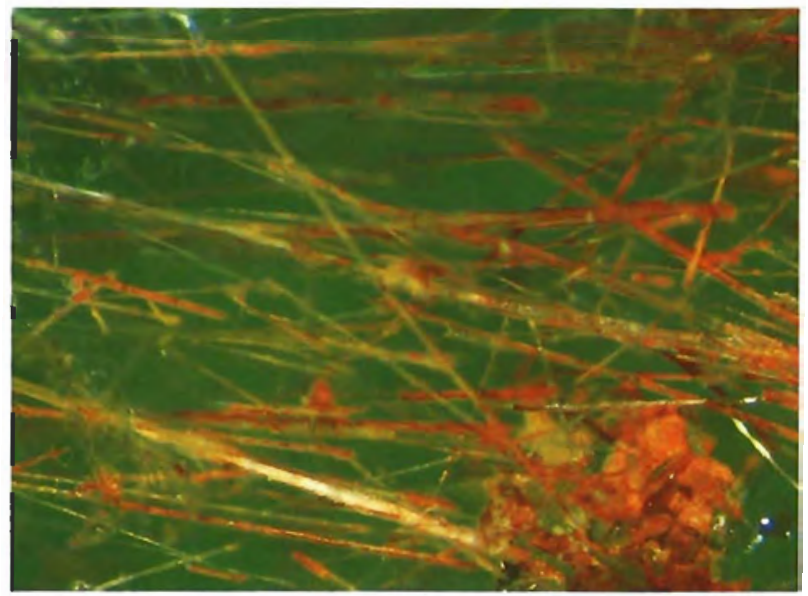


both being higher than the vanadium XRF peak. Smaller XRF peaks for potassium, calcium, cesium, and titanium were also detected in one or more samples. A quantitative chemical analysis (by electron microprobe) of an Egyptian emerald from Gebel Zabara (Grubessi et al., 1990) lists each of these elements except vanadium and cesium. All of the elements we detected in these samples are common in emeralds from many localities that we and others have analyzed.

The infrared spectra of these Egyptian emeralds appear to be similar to those of other natural emeralds and, not surprisingly, different from the spectra of flux- and hydrothermally grown synthetic emeralds (see Stockton, 1987). The spectra of one of the emeralds displayed features similar to those seen in emeralds that have been fracture filled. This supports the observations made regarding long-wave U.V. radiation and magnification.

\section{CONCLUSION}

The emerald and green beryl localities of upper Egypt have been mined, formally and informally, for more than 2,000 years. They are undoubtedly the earliest source of emeralds on record in the Western world.
Although there is no systematic mining at the present time, nomadic Bedouin pick through rain-washed gravels and ancient tailings to retrieve the small quantities of emeralds seen in local markets.

Gemological investigation of fashioned specimens obtained in Egypt revealed properties consistent with those reported in the literature for emeralds and green beryls from several other localities. Inclusions noted are typical of emeralds from other metamorphic environments and therefore cannot be used to characterize the locality.

Although many of the fragments seen in the ancient mine tailings and in situ at Gebel Zabara were light in tone and therefore more appropriately called green beryl, others were of sufficient depth of color to be called emerald. At present, however, because of the generally poor quality of this emerald as compared to that of emeralds from localities such as Colombia, Brazil, and Zambia, the prospects for increasing the supply of gem-quality emerald would appear to be too low to justify formal mining activity. Their greatest value lies in their role in the history of gemology and in the adornment of some of our early cultures.

\section{REFERENCES}

Aldred C. (1978) Jewels of the Pharaohs. Ballantine Books, New York.

Andrews C. (1991) Ancient Egyptian Jewelry. Harry N. Abrans, New York.

Basta E.Z., Zaki M. (1961) Geology and mineralization of Wadi Sikheit area, South-Eastem Desert. Journal of Geology, U.A.R., Vol. 5, No, 1, pp. 1-38.

Black I.A. (1981) A History of Jewelry. Park Lane, New York, N.Y.

Caygill M. (1985) Treasures of the British Museum. Harry N. Abrams, New York.

Geologic Map of Egypt, Gebel Hamata Sheet (1987). CONOCO/EGPC/TU Berlin Mapping Project, Institut für Angewardte Geodassie, Berlin.

Gregorietti G. (1969) Jewelry Through the Ages. American Heritage, New York.

Grubessi O., Aurisicchio C., Castiglioni A. (1990) The Pharoahs' forgotten emerald mines. Journal of Gemmology, Vol. 22, No. 3, pp. 164-177.

Gübelin E.J. (1982) Gemstones of Pakistan: Emerald, ruby, and spinel. Gems e) Gemology, Vol. 18, No. 3, pp. 123-139.

Gübelin E.J., Koivula J.I. (1986) Photoatlas of Inclusions in Gemstones. ABC Edition, Zurich.

Hassan M.A., El-Shatoury H.M. (1976) Beryl occurrences in Egypt. Mining Geology, Vol. 26, pp. 253-262.

Hume W.F. (1934) Geology of Egypt, Vol. 2, Part 1: The metamorphic rocks. Government Press, Cairo, pp. 105-125.

Hussein A.A. (1990) Mineral deposits. In Rushdi Said, Ed., The Geology of Egypt, A.A. Balkema, Rotterdan, Netherlands, pp. 537-539.

Liddicoat R. T. (1989) Handbook of Gem Identification, 12th ed. rev. Gemological Institute of America, Santa Monica, CA.
MacAlister D.A. (1900) The emerald mines of Northern Etbai. Geographical Journal, Vol. 16, pp. 537-549.

Middleton J.H. (1891) The Engraved Gems of Classical Times, with a Catalogue of the Gems in the Fitzwilliam Museum. Cambridge University Press, London, England.

Rogers F., Beard A. (1947) 5000 Years of Gems and lewelry. J.P. Lippincott Co., Philadelphia and New York.

Rohr M.K. (1990) Gems--The forgotten industry. Business Monthly, Journal of the American Chamber of Commerce in Egypt, Vol. 6, No. 11 , pp. 28-29.

Schmetzer K., Bernhardt H-J., Biehler R. (1991) Emeralds from the Ural Mountains. Gems es Gemology, Vol. 27, No. 2, pp. 86-99.

Schneider O. (1892) Der Aegyptische Smaragd. Zeitschrift für Ethnologie, Vol. 24, pp. 41-100.

Sinkankas J. (1981) Emerald and Other Beryls. Chilton Book Co, Radnor, PA, pp. 542-548.

Soliman M.M. (1986) Ancient emerald mines and beryllium mineralization associated with Precambrian stanniferous gran ites in the Nugrus-Zabara Area, Southeastem Desert, Egypt. Arab Gulf Journal of Scientific Research, Vol. 4, No. 2, pp. $529-548$.

Spier J. (1992) Ancient Gents and Finger Rings. Catalogue of the Collections, J. Paul Getty Museum, Malibu, CA.

Stockton C.M. (1987) The separation of natural from synthetic emeralds by infrared spectroscopy. Gems et) Gemology, Vol 23, No. 2, pp. 96-99.

Tait H., Ed. (1987) Jewelry: 7000 Years. Harry N. Abrams, New York.

Webster R. (1983) Gems, Their Sources, Descriptions and Identification, 4th ed. Revised by B.W. Anderson, Butterworths, London. 